\title{
Political uncertainty and stock market volatility: new evidence from the 2014 Scottish Independence Referendum
}

\author{
Julia Darby and Graeme Roy \\ Department of Economics, University of Strathclyde, Glasgow, UK \\ This version: March 2018 \\ Accepted for publication in the Scottish Journal of Political Economy \\ Date of acceptance 15 June 2018
}

\begin{abstract}
We investigate the impact of heightened political uncertainty in the run-up to, and after, the 2014 Scottish independence referendum. The conditional volatilities of stock returns of our Scottish index and the FTSE all share index are characterised by the same GARCH parameters for a sample ending in late 2013, but this no longer holds when estimation extends closer to the referendum. The relative volatility of Scottish companies' stock returns peaked when polls indicated the referendum result was "too close to call”, fell back on the result, but rose again in the run up to publication of proposals for further devolution.
\end{abstract}

Keywords: Scottish independence referendum; stock market volatility; political uncertainty.

Subject classification codes: C32; G10; G14.

Corresponding author: Julia Darby, email: julia.darby@strath.ac.uk, Department of Economics, University of Strathclyde, 130 Rottenrow, Glasgow, G4 OGE, UK.

Funding: Julia Darby gratefully acknowledges the support of ESRC grant ES/L003325/1 under The Constitutional Future of Scotland and the United Kingdom pre and post Referendum Initiative.

The authors are grateful to the editors, two referees, Graeme Meiklejohn, Mustafa Caglayan, Peter McGregor, Stuart McIntyre, participants at the 2017 Scottish Economics Society Conference for helpful discussions and suggestions. 


\section{Introduction}

This paper examines information from financial markets in the run up to, and immediately after, the 2014 Scottish Independence Referendum. To the best of our knowledge it is the first study to focus on the impact of this referendum on stock market volatility. The specific questions we address are: to what extent were companies headquartered in Scotland exposed to heightened uncertainty in the run-up to the Independence Referendum? Did the volatility of stock returns of these companies increase relative to a UK wide benchmark? Was any referendum induced uncertainty resolved after the result was known? And finally, how robust are our findings?

Heightened stock market volatility matters in part because it is likely to discourage new share issues and initial public offerings and can impacts on lenders' risk assessments and therefore borrowing costs. Recent research, for example Bloom, Baker and Davis (2013), has suggested that political uncertainty can increase unemployment and reduce investment, particularly if sustained.

We demonstrate, for the early part of our sample, that the conditional volatilities of the Scottish stock returns and of returns in the FTSE all share index can be characterised by the same GARCH parameters, but that this is no longer the case once estimation extends beyond mid December 2013. Our estimates show that the relative stock market volatility of Scottish companies’ stock returns peaked in early September 2014, when the polls suggested the referendum result was too close to call, fell back after the result was known, but built up again prior to the publication of a report - the Smith Commission - into Scotland's future in the UK in November 2014. We find these findings are robust to the inclusion/exclusion of the Royal Bank of Scotland and to the 
exclusion of the whole of the Scottish financial and oil and gas sectors.

The remainder of the paper proceeds as follows: section 2 briefly discusses the related literature and section 3 sets out a timeline of key events in the 2014 Scottish independence referendum. In section 4 we explain how we identify the publicly listed companies in Scotland and describe our data. Section 5 outlines our econometric methodology. Section 6 presents the key results. Robustness checks are carried out in section 7 and section 8 concludes.

\section{Related literature}

There are few empirical studies of the impact of referendums on stock market volatility. Nonetheless numerous studies have examined stock market volatility around the time of elections: these include Goodell and Vähämaa (2013) and Li and Born (2006) who focused on US presidential elections; Smales (2014) for Australian elections; and Bialkowski, Gottschalk and Wisniewski (2008) who studied evidence for 27 OECD countries. Each of these studies concluded that elections are accompanied by a significant hike in stock market volatility, which is more pronounced in close contests. They also point to cases in which the excessive volatility could not be resolved quickly, e.g. when the political orientation of the government changes or when an election was inconclusive. These results are consistent with the theoretical predictions of Pástor and Veronesi (2012, 2014). Vuchelen (2003) stresses that within a coalition based political system, election results may eliminate some possibilities but that more decisive positions only become clear once a new coalition has been announced. The same is likely to be true of a referendum outcome when the timing and nature of the next steps are unclear. 
Arin, Molchanov and Reich (2013) examined the effects of a number of political variables on stock returns and their volatilities in a panel of 17 parliamentary democracies spanning the post-war period to 1995 . They presented a strong empirical case that the effects of political variables on stock return volatilities are considerably stronger than the effects of these variables on stock returns.

Far fewer studies have explored how political uncertainty influences financial markets outside the election cycle. An exception, with some similarities to our own, is Beaulieu, Cosset and Essadam (2006). They focus on the 1995 Quebec referendum which could have led to the separation from the Canadian federation. As in the Scottish case, opinion polls did not point to a clear winner, so uncertainty associated with the referendum could not be resolved prior to the vote. Even after the Quebec result, when $50.6 \%$ voted 'no', it was not clear that the referendum resolved uncertainty with respect to Quebec's future. And in the Scottish case, it was made clear even before the vote that neither a 'yes' or 'no' vote would result in prolonging the status quo, as explained in section 3, so again the result alone may not have been sufficient to resolve uncertainty.

The impact of the resolution of uncertainty on asset volatility has been investigated in several papers that look at the impact of scheduled information releases. The consensus is that volatility in financial markets tends to: i) be significantly greater on announcement days than on other days; ii) remain significantly higher for several hours after the information release; and iii) dissipates rapidly as uncertainty is resolved; see for example, Smales (2013), Vähämaa and Äijö (2011), Donders and Vorst (1996) and Ederington and Lee (1996, 1993). 
The Beaulieu et al. (op. cit.) study of the impact of the Quebec referendum provides a helpful starting point for our own work. They sought to contrast the impact of the uncertainty about the referendum outcome on the stock returns of 71 Quebec firms as compared to a sample of Canadian (excluding Quebec) and U.S. firms. They found that uncertainty surrounding the referendum had a significant, but ultimately short-term impact on the stock returns of Quebec firms and concluded that the reaction of financial markets to the referendum was indicative of resolution of uncertainty.

\section{The Scottish Independence Referendum Timeline}

The Scottish Parliament election of $5^{\text {th }}$ May 2011 gave First Minister, Alex Salmond the mandate to hold the Scottish Independence Referendum. Negotiations between the UK and Scottish governments over the necessary constitutional arrangements culminated in the Edinburgh Agreement, signed on $15^{\text {th }}$ October 2012. The wording of the referendum question was agreed on 30th January the following year, with the date of the vote announced on $21^{\text {st }}$ March 2013, and set at $18^{\text {th }}$ September 2014.

Information on voting intentions was initially captured relatively infrequently, but intensified as the Referendum date approached, see for example National Centre for Social Research (2014). In the final month, a total of 20 polls were conducted by British Polling Council members and the gap between the proportions of those intending to vote 'yes’ and 'no' narrowed. Of particular note was a YouGov poll conducted for the Sunday Times ( $7^{\text {th }}$ September 2014) which found that 51 per cent of voters in Scotland would back independence, with 49 per cent opposed (undecided voters excluded). This marked a four point increase in support for a Yes vote in less than a week. Soon after, a TNS poll made public on the night of $8^{\text {th }}$ September put the two campaigns neck and 
neck. Writing on $9^{\text {th }}$ September 2014, Professor John Curtice - one of the UK’s most respected psephologists - expressed a common view:

"As a result of today's poll, our poll of polls... has been updated. On that measure Yes support has edged up again and now stands at 48\%, with No on 52\%. The referendum race is now clearly too close to call." http://blog.whatscotlandthinks.org/2014/09/tns-now-say-it-is-a-dead-heat/

There followed a flurry of activity that included publication of 'The Vow', two days before the vote, in which leaders of the three main UK parties campaigning against independence committed to “extensive new powers” for the Scottish Parliament, should voters opt to remain within the $\mathrm{UK}^{1}$.

Following the vote and victory for the 'no’ side, the Prime Minister, David Cameron immediately established the Smith Commission, to deliver on 'The Vow'. The Smith Commission reported, making a number of recommendations, on 27th November 2014; legislation based on these recommendations was implemented in the Scotland Act 2016, which received Royal Assent on $23^{\text {rd }}$ March 2016.

During the referendum campaign, many Scottish companies were initially reluctant to make explicit statements either in favour or against Scottish independence, but some were required by their corporate governance rules to inform their investors of any contingency plans. These included two of the country’s largest financial services companies Standard Life and Royal Bank of Scotland (see Financial Times (2014)). Mainstream media published many stories around the consequences of independence, while the UK Government's campaign put economic uncertainty at the heart of much of

1 “The Vow", a letter signed by the three main UK party leaders, appeared on the front page of the Daily Record on $16^{\text {th }}$ September 2014, see http://www.dailyrecord.co.uk/news/politics/david-cameron-edmiliband-nick-4265992. 
its argument for Scotland remaining in the UK (UK Government, 2014).

This timeline of events informs our choice of sample period: to capture key events in the run-up to the referendum date, the estimation period starts on $6^{\text {th }}$ April 2010 (one month before the UK General Election); and to ensure that we can examine how any financial market impacts of uncertainty surrounding the referendum result were resolved after the results were announced, our sample end date extends to $4^{\text {th }}$ June 2015 (one month after the 2015 UK General Election). We avoid extending the sample beyond this, e.g. to include the run up to the Brexit referendum, in order to focus on the period in which Scotland could reasonably be seen to be experiencing uncertainty distinctive to that facing the UK as a whole.

\section{Data}

In order to construct a Scottish stock price index it is first necessary to identify companies listed on the LSE that can be classified as 'Scottish'. Key criteria we apply are i) that selected companies had headquarters in Scotland; and/or ii) their major operations were located within Scotland, during all, or part of, the sample period investigated. A similar strategy is discussed in Marsh and Evans (2014) although they chose to include Investment Trusts in their index, while we exclude them since from our perspective they are best seen as investment vehicles that have a limited 'footprint' within the local economy ${ }^{2}$.

\footnotetext{
2 Marsh and Evans (op cit.) reported that 10 of the top 20 Scottish listed companies by market capitalisation at the start of 2014 were Investment Trusts, "with an astonishing 26\% weighting” while this sector has “...just a $3 \%$ weighting within the UK as a whole" p4. Based on the reference point of the August 2013 historical files from the LSE, we disregarded prices of 39 shares that Marsh and Evans would have included: for 31 'Equity or Non-Equity Investment Instruments', 2 'Real Estate Holding and Development' companies, 3 'Specialty Finance' companies and 3 'Debenture and Loan' companies. Other
} 
In principle, an alternative approach could be to look at all UK based listed companies' exposure to the potential outcomes of the referendum, differentiating by whether they have any operations in Scotland or not, and by what proportion of their revenues are attributable to sales in Scotland, or by the proportion of their total UK employees located in Scotland. However this kind of information is simply not available. In any case, uncertainty around independence was not just about how well Scotland would perform economically, it was also about fundamental legal and constitutional structures, economic rules and regulations, membership of the EU and applicability of global treaties and so on. Many of these factors would have a distinctive impact on companies headquartered in Scotland, not just how exposed they were by market share. So, for example, two financial services companies with equal market share in Scotland faced a completely different set of risks if one was registered in London and the other in Edinburgh.

Several sources inform our approach to selecting Scottish listed companies: until August 2013, the London Stock Exchange’s historical files provide a 'region' indicator for each company; issues of Business Insider Magazine provide a list of 'Scotland's quoted companies'; and information from these sources was cross-checked against Annual Reports and registration information lodged at Companies House. Annual reports also provide dates of relevant relocations, mergers, closures or de-listings. A total of 64 Scottish companies listed on the London stock exchange were identified for inclusion in our constructed Scottish stock market index for at least some part of our

differences in the number of listed shares reflect exclusions following scrutiny of annual Companies House reports, as discussed in the main text. 
sample period, April 2010 -June 2015. Table 1 summarises the data.

Table 1. Numbers of Scottish companies listed on the London Stock Exchange

\begin{tabular}{lcccccccc}
\hline & End Year & 2010 & 2011 & 2012 & 2013 & 2014 & 2014 & 2016 \\
\hline Number of companies & 56 & 56 & 51 & 48 & 48 & 45 & 40 \\
Entrants during the year & 4 & 3 & 2 & 0 & 1 & 0 & 0 \\
Exits during the year & 1 & 3 & 7 & 3 & 1 & 3 & 5 \\
\hline
\end{tabular}

Source: authors' calculations.

Within any one year there were at most 56 Scottish companies in the index ${ }^{3}$.

Companies are included in our Scottish stock price index from the start of the sample

or, where relevant, from the date of listing, up until any date of relocation, merger -

with parent company located outside of Scotland, or delisting. This approach contrasts

with that used in Beaulieu et al. (op cit.) where Quebec based companies were included

in their sample only if listed and headquartered in Quebec at the date of the referendum.

In practice this would, for example, miss out any companies that made a strategic move

to relocate their HQ prior to the referendum, any companies making a new listing, or

existing listed companies transferring their HQ to Quebec after the referendum. Given

the changes observed over our sample period, we believe it is important to avoid any

potential bias that could arise from focusing only on companies that were headquartered

in Scotland on the date of the referendum.

3 The number of Scottish listed companies fell over the sample period, and no Scottish companies were newly listed on the LSE since the referendum in our sample period, the last being Exova Group (a leading provider of laboratory based testing and related advisory services, founded in 2008 and headquartered in Edinburgh) who were first listed on the LSE in April 2014. There are no obvious common features among the eleven companies dropped from the list of Scottish listed companies between the date of the Scottish election in May 2011 and the Independence referendum in September 2014; nor among the eight companies that have delisted from the LSE since the independence referendum. Furthermore, none of these companies made any mention of the referendum featuring in their decision making with respect to mergers, listing or delisting in the relevant years' annual report. More details are provided in an appendix in Darby and Roy (2017). 
Beaulieu et al. constructed a matched sample of Quebec and US/Canadian companies using capitalisation and other data as close to the date of the referendum as possible. We were keen to avoid the short-cut of fixing capitalisation weights throughout the sample period. Even a cursory look at the variation in the market capitalisation of the top 10 Scottish listed companies at some key dates suggests this would be unwise, see Darby and Roy (2017) for details. We therefore collected daily data on both market capitalisation and stock prices for each Scottish listed company from Datastream, and chose to construct a capitalisation weighted stock price index in which the capitalisation weights are updated each period, thereby mimicking the construction of the FTSE indices as closely as possible.

The presence of the Royal Bank of Scotland (RBS) in our sample raises some 'interesting' issues. As is well known, RBS received a substantial bail-out during the financial crisis. Throughout our sample period the UK Government held $81 \%$ of the company’s shares. Given the peculiarities of this special case, our core sample excludes RBS shares from the Scottish share price index. More generally the finance sector makes up a large, and growing, part of the Scottish stock price index than the FTSE over the sample period ${ }^{4}$. Oil and gas as also historically had strong representation among Scotland's listed companies and has also been subjected to particular challenges over the period we investigate: oil prices fell from around \$100 per barrel in 2014 to half that by the end of 2015. These considerations motivate construction of a number of additional indices which are used in the robustness checks discussed in Section 7.

\footnotetext{
${ }^{4}$ Details on market capitalisation by sector are provided in Darby and Roy (2017).
} 
Daily data for the FTSE all share index is used as a benchmark to compare and contrast the volatility of the Scottish indices ${ }^{5}$. The FTSE all share index is chosen over the FTSE100 or FTSE250 since relatively few Scottish companies are represented in these alternative indices. We discuss the suitability our choice of the FTSE all share index as the benchmark index further in Section 6. Summary statistics for the key series investigated over the full sample, i.e. all trading days from 6th April 2010 to 4th June 2015, are provided in Table 3.

Table 2. Summary Statistics for Daily Percentage Change in Stock Price Indicies

\begin{tabular}{|c|c|c|c|c|}
\hline Sample: $N=1304$ & $\begin{array}{l}\text { FTSE all share } \\
\text { index }\end{array}$ & $\begin{array}{l}\text { Scottish } \\
\text { Index }\end{array}$ & $\begin{array}{c}\text { Scottish exc. } \\
\text { RBS }\end{array}$ & $\begin{array}{l}\text { Scottish exc. } \\
\text { finance sector }\end{array}$ \\
\hline Mean & 0.023 & 0.023 & 0.040 & 0.029 \\
\hline Std. deviation & 0.957 & 1.322 & 1.034 & 1.012 \\
\hline Skewness & -0.132 & -0.033 & -0.236 & -0.260 \\
\hline Kurtosis & 5.490 & 5.666 & 4.992 & 5.379 \\
\hline Maximum & 5.154 & 8.440 & 4.506 & 4.293 \\
\hline Minimum & -4.490 & -6.995 & -5.488 & -5.767 \\
\hline $\begin{array}{l}\text { Shapiro-Francia } \\
\text { test ( } \mathrm{H}_{0} \text { : normality) }\end{array}$ & $7.697[.00]$ & $7.142[.00]$ & $6.816[.00]$ & $7.155[.00]$ \\
\hline Skewness t-test & $-1.948[.05]$ & $-0.481[.63]$ & $-3.437[.00]$ & $-3.842[.00]$ \\
\hline Ex.Kurtosis t-test & $18.35[.00]$ & $19.65[.00]$ & $17.54[.00]$ & $17.54[.00]$ \\
\hline ARCH $1 \quad \chi^{2}(1)$ & $39.98[.00]$ & $48.58[.00]$ & $35.31[.00]$ & $40.39[.00]$ \\
\hline ARCH $5 \quad \chi^{2}(5)$ & $148[.00]$ & $131[.00]$ & $126[.00]$ & $131[.00]$ \\
\hline ARCH $10 \chi 2(10)$ & $171[.00]$ & $167[.00]$ & $170[.00]$ & $197[.00]$ \\
\hline
\end{tabular}

Probability values for the various tests are shown in [.].

${ }^{5}$ This avoids the need to match each individual Scottish listed company with a 'similar' company located elsewhere in the UK - mirroring Beaulieu et al. (2006). In our view, attempting this kind of matching would be both non-trivial and, in many cases, controversial. 
On the basis of the Shapiro-Francia test, the null hypothesis that the respective stock returns series are normally distributed is rejected conclusively in each case. The appropriate t-tests of $\mathrm{H}_{0}$ : skewness $=0$ and $\mathrm{H}_{0}$ : no excess kurtosis are consistent with significant skewness in most, but not all, cases and excess kurtosis in every case. In addition, normal quantile plots are suggestive of symmetric distributions with fat tails; that is, extreme positive and negative values of returns occur more frequently in the data than would be consistent with the normal distribution. The final three tests reported in Table 2 provide evidence of significant autoregressive conditional heteroscedasticity in each series, which is supportive of the need for the GARCH modelling strategy adopted in this paper.

\section{Econometric Methodology}

We estimate both bivariate and univariate GARCH models in order to capture the conditional volatility of Scottish stock returns on the one hand and returns on the FTSE all share index on the other. We investigate whether lags of returns series play any significant role, either individually or jointly, in the mean equations. Our expectation is that they will not, in line with the common finding that stock returns are unpredictable. Following Bollerslev, Engle and Wooldridge (1988), the bivariate models employ the relatively parsimonious diagonal VECH representation which assumes the conditional covariance matrix is diagonal, meaning that the variance and covariance of each series depends only on its own past history. Specifically, the bivariate DVECH-GARCH(1,1) model specifies the conditional variances and covariance equations as follows: 


$$
\begin{aligned}
& \mathrm{h}_{11 \mathrm{t}}=\sigma_{1, \mathrm{t}}^{2}=\varpi_{11}+\alpha_{11} \varepsilon_{1, \mathrm{t}-1}^{2}+\beta_{11} \sigma_{1, \mathrm{t}-1}^{2} \\
& \mathrm{~h}_{12 \mathrm{t}}=\sigma_{1, \mathrm{t}} \sigma_{2, \mathrm{t}}=\varpi_{12}+\alpha_{12} \varepsilon_{1, \mathrm{t}-1} \varepsilon_{2, \mathrm{t}-1}+\beta_{12} \sigma_{1, \mathrm{t}-1} \sigma_{2, \mathrm{t}-1} \\
& \mathrm{~h}_{22 \mathrm{t}}=\sigma_{2, \mathrm{t}}^{2}=\varpi_{22}+\alpha_{22} \varepsilon_{2, \mathrm{t}-1}^{2}+\beta_{22} \sigma_{2, \mathrm{t}-1}^{2}
\end{aligned}
$$

Under the assumption of conditional normality the system of equations that characterise the model can be estimated by maximum likelihood. The standard GARCH coefficients, $\left\{\alpha_{11} \beta_{11} \alpha_{22} \beta_{22}\right\}$ capture how lagged shocks and conditional volatilities impact on the current conditional volatilities. The coefficient $\alpha_{12}$, attached to the past product term $\varepsilon_{1, \mathrm{t}-1} \varepsilon_{2, \mathrm{t}-1}$, captures co-movements across markets, while the coefficient $\beta_{12}$ on the term $\sigma_{1, \mathrm{t}-1} \sigma_{2, \mathrm{t}-1}$ captures the persistence of covariance. Likelihood ratio tests of the null hypothesis of a constant conditional covariance matrix are reported to check whether it is data admissible for the parameters $\left\{\alpha_{11} \beta_{11} \alpha_{12} \beta_{12} \alpha_{22} \beta_{22}\right\}$ to be jointly restricted to 0. Within this bivariate set-up, we also test the null hypothesis that the conditional volatilities of the two series can be characterised by the same GARCH process, that is $\alpha_{11}=\alpha_{22}$ and $\beta_{11}=\beta_{22}$. If data admissible, at least over some part of the sample period, this provides some justification for using the FTSE all share index as a benchmark against which to compare volatilities Scottish companies’ stock returns.

One disadvantage of bivariate GARCH modelling is the imposition of symmetry in the effects of positive and negative shocks. Separate univariate modelling allows us to relax this assumption. Both exponential (EGARCH) and threshold (TGARCH) models, proposed by Nelson (1991) and Glosten, Jagannathan and Runkle (1993) respectively, are found to be more appropriate than the simple GARCH model for our data. This is not unexpected and is in line with common findings that 'bad news', in the 
form of a drop in the share price index, tends to be followed by higher volatility than 'good news', i.e. a rise in the index of the same magnitude. The precise specifications of the conditional volatility equations in each of these cases is are shown below:

$$
\begin{array}{ll}
\operatorname{GARCH}(1,1): & \mathrm{h}_{\mathrm{t}}=\sigma_{\mathrm{t}}^{2}=\varpi+\alpha \varepsilon_{\mathrm{t}-1}^{2}+\beta \sigma_{\mathrm{t}-1}^{2} \\
\operatorname{EGARCH}(1,1): & \ln \mathrm{h}_{\mathrm{t}}=\varpi+\beta \ln \sigma_{\mathrm{t}-1}^{2}+\gamma \frac{\varepsilon_{\mathrm{t}-1}}{\sigma_{\mathrm{t}-1}}+\alpha \frac{\left|\varepsilon_{\mathrm{t}-1}\right|}{\sigma_{\mathrm{t}-1}} \\
\operatorname{TGARCH}(1,1): & \mathrm{h}_{\mathrm{t}}=\sigma_{\mathrm{t}}^{2}=\varpi+\alpha \varepsilon_{\mathrm{t}-1}^{2}+\gamma \mathrm{d}_{\mathrm{t}-1}^{+} \varepsilon_{\mathrm{t}-1}^{2}+\beta \sigma_{\mathrm{t}-1}^{2} \\
& \text { where } \mathrm{d}_{\mathrm{t}-1}^{+}=1 \text { if } \varepsilon_{\mathrm{t}-1}>0, \text { and }=0 \text { otherwise. }
\end{array}
$$

A further issue to be confronted in univariate modelling is the distribution assumed in estimation. Initial examination of our data, summarised in Table 2, indicated that the returns series are far from normally distributed: each displays significant skewness and excess kurtosis. We therefore estimate GARCH, EGARCH and TGARCH models for each of returns series under three different distributional assumptions: asymptotic normality with Wooldridge's robust standard errors; the Student's t distribution; and the generalised error distribution (GED). Provided that the models are correctly specified, all three estimators are consistent, but given fat tails, we expect Student's t and GED based estimates to be more efficient than those that assume asymptotic normality. In each case the preferred specification is chosen in line with standard practice, on the basis of: i) the significance of the estimated parameters; ii) diagnostic tests; and iii) minimising the relevant information criterion.

Once the preferred models are selected, the time series for the estimated conditional variances can be examined. At this point we can seek evidence of any widening divergence in the conditional volatility of stock returns of the Scottish companies relative to that of the UK benchmark series. We can identify any time periods in which 
major divergences occur and check to see if these periods are associated with key events in the timeline of the independence referendum as set out in section 2. By checking whether any divergence persists or is resolved as time passes, we are able to explore whether there is evidence of clear financial market impact of the political uncertainty generated by the independence referendum.

\section{Results}

\subsection{Bivariate GARCH results}

The first set of results, shown in column 1 of Table 3, are DVECH-GARCH estimates that jointly model the mean, variances and covariance of the stock returns from the Scottish index excluding RBS, and in the FTSE all share index over the full sample period. Columns (1) and (2) report the unrestricted and restricted estimates of the model for the full sample. The mean equations include an intercept and the first lags of each of the returns series in each equation, ie. stock returns are modelled using a VAR of order 1 . The lagged terms are not significant individually but are retained given their joint significance (indicated in the first of the likelihood ratio tests provided in the table $)^{6}$. The second set of likelihood ratio tests indicate that the null hypothesis of constant variances and covariance is strongly rejected in every case, supporting modelling of time varying conditional variances and covariances.

The null hypothesis that the two returns series are characterised by the same ARCH and GARCH parameters is strongly rejected over the full sample, as indicated in the likelihood ratio test at the foot of column (2) of Table 3, and its respective p-value. However, columns (3) and (4) indicate that this result is overturned when estimation

\footnotetext{
${ }^{6}$ Although the same inference with respect to the other parameters of the model holds, whether the mean equations contain a lag of each returns series or just an intercept term.
} 
ends on $15^{\text {th }}$ October 2012, at the point that the Edinburgh Agreement was signed. For this shorter sample we are unable to reject the null hypothesis that the two returns series are characterised by the same GARCH process, as indicated in the second likelihood ratio test shown at the foot of column (4). We appeal to this result to justify our use of the FTSE all share index as a benchmark against which to compare the volatility of Scottish stock returns.

Table 3. Bivariate DVECH GARCH estimates

\begin{tabular}{|c|c|c|c|c|}
\hline & \multicolumn{2}{|c|}{ Full Sample: 6/4/10-4/6/15 } & \multicolumn{2}{|c|}{ Sub-Sample: 6/4/10-15/10/12 } \\
\hline & (1) & $(2)$ & (3) & (4) \\
\hline \multicolumn{5}{|c|}{ Mean equations } \\
\hline$\mu_{1}$ & $0.061(0.025)[.01]$ & $0.064(0.025)[.01]$ & $0.084(0.041)[.04]$ & $0.084(0.040)[.04]$ \\
\hline$\mu_{2}$ & $0.042(0.022)[.06]$ & $0.045(0.022)[.04]$ & $0.033(0.039)[.41]$ & $0.034(0.039)[.39]$ \\
\hline$\mu_{11}$ & $-0.025(0.053)[.64]$ & $-0.022(0.053)[.68]$ & $-0.039(0.088)[.66]$ & $-0.039(0.088)[.66]$ \\
\hline$\mu_{12}$ & $0.053(0.058)[.36]$ & $0.053(0.058)[.36]$ & $0.079(0.090)[.38]$ & $0.083(0.090)[.36]$ \\
\hline$\mu_{21}$ & $0.043(0.047)[.36]$ & $0.046(0.046)[.32]$ & $0.098(0.083)[.24]$ & $0.097(0.084)[.25]$ \\
\hline$\mu_{22}$ & $-0.049(0.053)[.35]$ & $-0.050(0.053)[.35]$ & $-0.095(0.087)[.27]$ & $-0.089(0.087)[.30]$ \\
\hline \multicolumn{5}{|c|}{ Variance and Covariance equations } \\
\hline$\varpi_{11}$ & $0.059(0.015)[.00]$ & $0.054(0.019)[.01]$ & $0.050(0.019)[.01]$ & $0.045(0.018)[.01]$ \\
\hline$\varpi_{12}$ & $0.031(0.008)[.00]$ & $0.039(0.014)[.01]$ & $0.033(0.012)[.01]$ & $0.037(0.015)[.01]$ \\
\hline$\varpi_{22}$ & $0.026(0.008)[.00]$ & $0.042(0.015)[.01]$ & $0.031(0.013)[.02]$ & $0.042(0.017)[.01]$ \\
\hline$\alpha_{11}$ & $0.066(0.012)[.00]$ & $0.074(0.016)[.00]$ & $0.050(0.011)[.00]$ & $0.052(0.012)[.00]$ \\
\hline$\alpha_{12}$ & $0.056(0.011)[.00]$ & $0.069(0.015)[.00]$ & $0.046(0.010)[.00]$ & $0.049(0.011)[.00]$ \\
\hline$\alpha_{22}$ & $0.056(0.012)[.00]$ & $0.074(0.016)[.00]$ & $0.050(0.012)[.00]$ & $0.052(0.012)[.00]$ \\
\hline$\beta_{11}$ & $0.871(0.025)[.00]$ & $0.868(0.034)[.00]$ & $0.908(0.022)[.00]$ & $0.909(0.022)[.00]$ \\
\hline$\beta_{12}$ & $0.899(0.019)[.00]$ & $0.874(0.032)[.00]$ & $0.921(0.017)[.00]$ & $0.913(0.021)[.00]$ \\
\hline$\beta_{22}$ & $0.908(0.020)[.00]$ & $0.868(0.034)[.00]$ & $0.922(0.019)[.00]$ & $0.909(0.022)[.00]$ \\
\hline
\end{tabular}

LR test - dropping lagged terms in the mean equations - $\mathrm{H}_{0}: \mu_{11}=\mu_{12}=\mu_{21}=\mu_{22}=0$ $\chi^{2}(4)=12.00[.02] \quad \chi^{2}(4)=18.08[.00]$

LR test - constant variances and covariances $-\mathrm{H}_{0}: \alpha_{11}=\alpha_{12}=\alpha_{22}=\beta_{11}=\beta_{12}=\beta_{22}=0$

$$
\chi^{2}(6)=250[.00] \quad \chi^{2}(6)=94.16[.00]
$$

LR test - same parameters in GARCH processes $-\mathrm{H}_{0}: \alpha_{11}=\alpha_{22}$ and $\beta_{11}=\beta_{22}$.

$$
\chi^{2}(2)=8.29[.02] \quad \chi^{2}(2)=2.86[.24]
$$

Notes: $\quad$ 1. Estimation is by maximum likelihood and was conducted using Stata 14.

2. Series 1 is the Scottish index, excluding RBS; series 2 is the FTSE all share index.

3. Standard errors are given in (.) and probability values are provided in [.].

4. Restricted parameters are shown in bold in columns (2) and (4). 
We next investigate at what point the volatility of Scottish stock returns differs significantly from returns on the FTSE using recursive estimation and testing of the unrestricted and restricted models. As explained in Section 5, these results are indicative, since sequential tests of this kind are not formally statistically independent.

Table 4. LR tests of the null hypothesis that the conditional volatilities of the two series are characterised by the same GARCH parameters - the effect of rolling forward the sample end date

\begin{tabular}{|c|c|c|}
\hline Sample end date & Event & LR test [p-value] \\
\hline 15 $5^{\text {th }}$ October 2012 & Edinburgh Agreement & $2.86 \quad[.239]$ \\
\hline $30^{\text {th }}$ January 2013 & Referendum Question set & 2.52 [.283] \\
\hline 21 ${ }^{\text {st }}$ March 2013 & Date of Referendum announced & $3.50 \quad[.174]$ \\
\hline 26 $6^{\text {th }}$ November 2013 & 'Blueprint for Independence' & $5.74 \quad[.057]$ \\
\hline 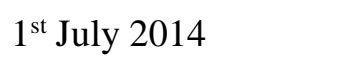 & Scottish Independence Bill & $9.16 \quad[.010]$ \\
\hline $18^{\text {th }}$ September 2014 & Referendum & $9.34 \quad[.009]$ \\
\hline
\end{tabular}

The results indicate that by the time of the publication of the 'Blueprint for Independence' in November 2014, the Scottish series had already begun to deviate from that of the FTSE: the LR test indicates that the null hypothesis of equality of the GARCH parameters is rejected at the $10 \%$ level of significance. Rejection of the null is stronger, at the $1 \%$ level of significance, when estimation extends through to the publication of the Scottish Independence Bill in July 2014. Analysis in which the estimation period initially stops 18 months before the referendum date, but is then extended at monthly intervals, is reported in Darby and Roy (2017) and shows that the null hypothesis that the same GARCH parameters can adequately describe the volatility of returns for both the FTSE all share index and the Scottish index is rejected at the $10 \%$ level of significance, or less, for estimation periods that end on 18th June 2013 onwards, ie. 15 months prior to the 
referendum, furthermore the relevant probability values are strictly decreasing over the 5 months prior to the referendum.

\subsection{Univariate models}

As explained above, there are some disadvantages of multivariate GARCH models: in practice, univariate models are more flexible, so may be better able to capture some aspects of the data, also the opportunity to make alternative distributional assumptions offers potential efficiency gains. Estimates of our preferred univariate models estimated over the full sample are presented in Table 5.

Table 5. Univariate Modelling of Stock Returns

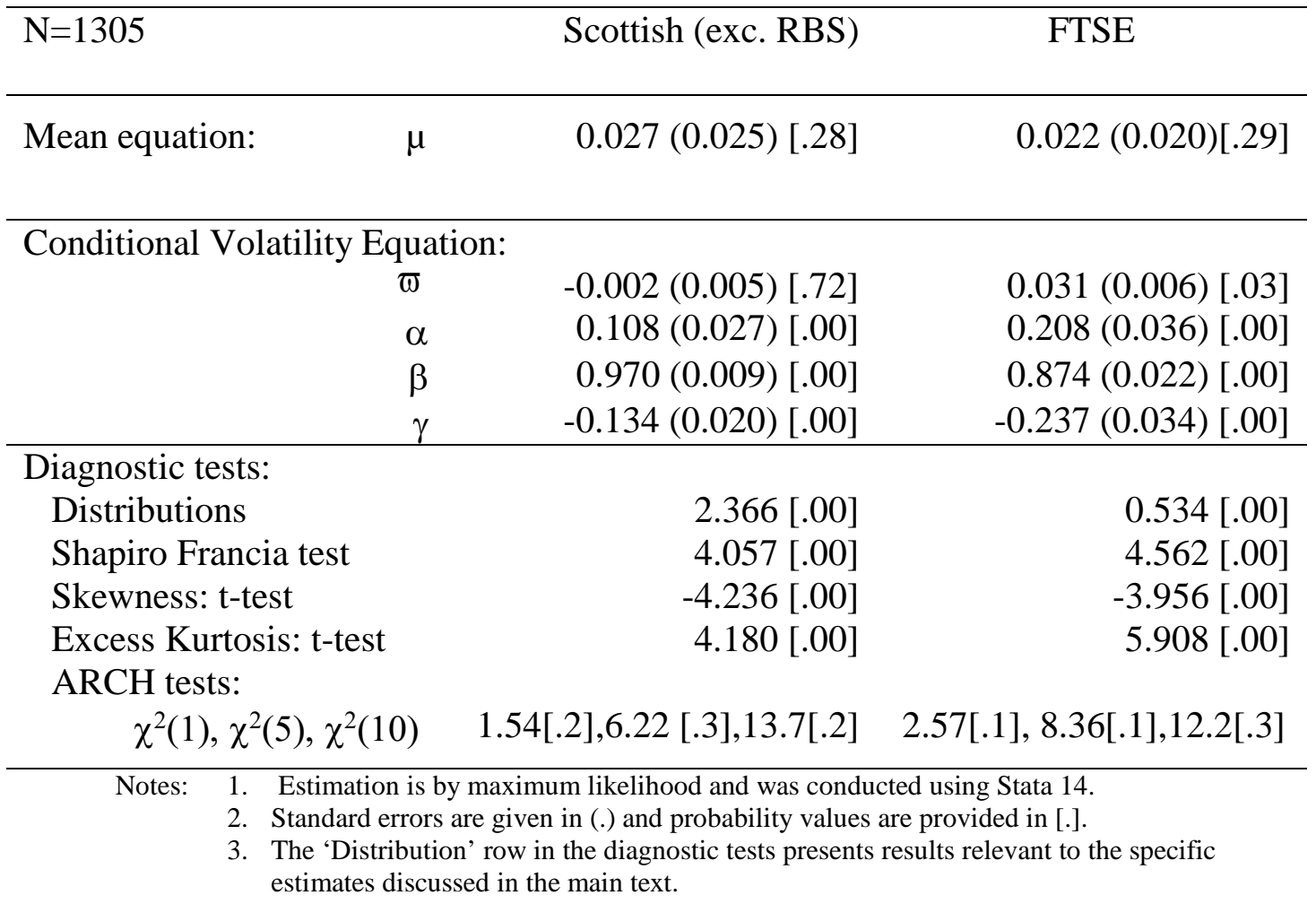

Diagnostic tests, constructed using standardised residuals, indicate that the null hypothesis of normality and is always rejected; that there is significant excess kurtosis, and skewness, highlighting that alternative distributional assumptions are likely to deliver efficiency gains. ARCH tests indicate that the models of conditional volatility 
are sufficient to fail to reject the null hypothesis of no remaining autoregressive heteroskedasicity in the (squared) standardised residuals of order 1 , up to 5 or up to 10 . Further discrimination between the set of estimated models is feasible through use of the information criteria, leading us to choose the GED estimates of the TGARCH model for the FTSE returns; and the EGARCH estimates that assume the Student's tdistribution for the Scottish (excluding RBS) series ${ }^{7}$. We next examine the estimated conditional volatilities of stock returns. Figure 1 plots the estimated conditional volatilities derived from the preferred models over the full sample period.

Figure 1: Estimated Conditional Volatilities of Stock Returns

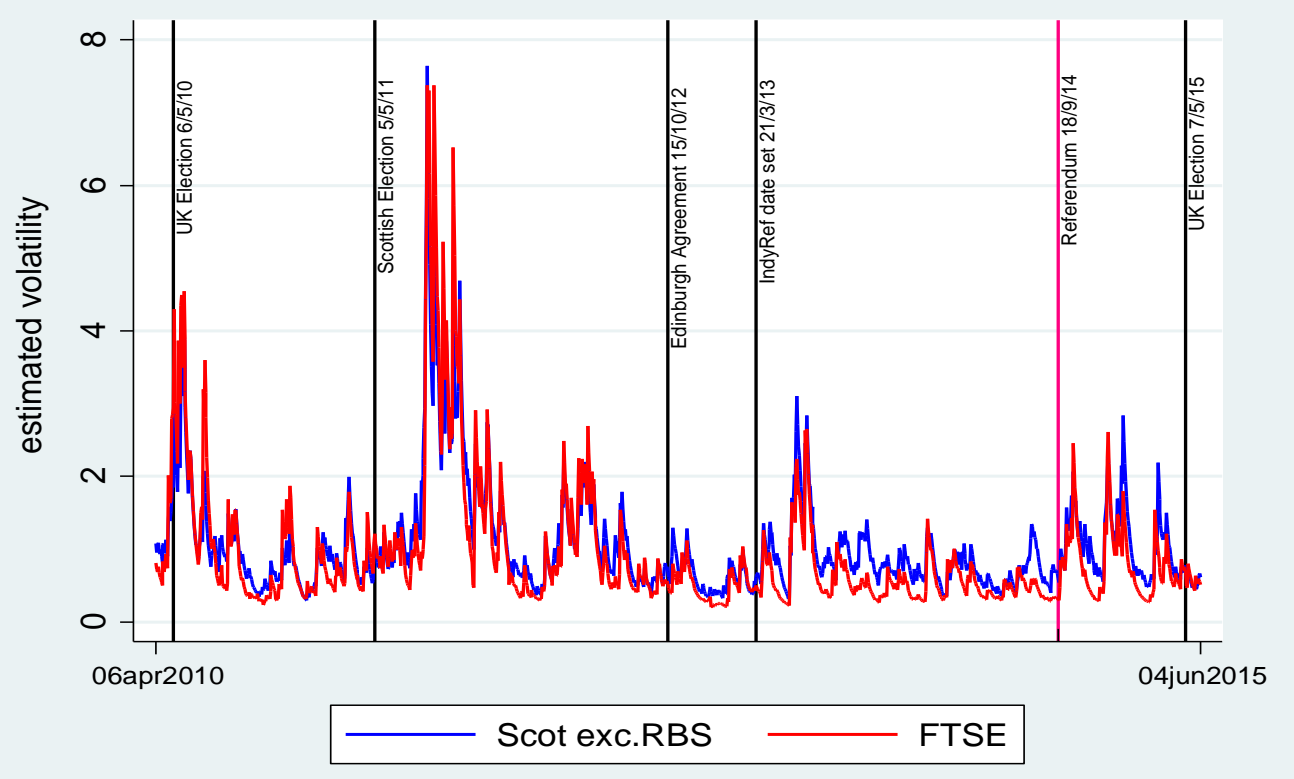

The two series are clearly highly correlated with each other. This is not surprising: most listed companies operate in global markets and are impacted by the same issues - e.g. swings in stock market sentiment in Wall Street. Similarly, there are

${ }^{7}$ Only the preferred specifications are presented here, in the interests of brevity. Full results for returns in the FTSE, Scottish and Scottish exc. RBS series are provided in Tables 7a, 7b and 7c of Darby and Roy (2017). 
close linkages between the Scottish and rUK economies. The similarity in the estimated volatilities for the first part of the sample adds to evidence discussed in section $6.1^{8}$.

The date of the independence referendum is indicated on the graph with a red vertical line. Volatility was relatively low at this point in comparison to some other dates illustrated. For example, the greater hike in volatility associated with the European debt crisis of 2011 is easily identified, as is that following the UK general election in $2010^{9}$. However, in common with results reported in section 6.1, note that Scottish and FTSE conditional volatilities look to diverge in the period running up to the referendum and beyond, with the Scottish series showing higher relative volatility. This divergence can be seen most clearly in Figure $2 \mathrm{a}$ and $2 \mathrm{~b}$, which zoom in on the period spanning three months prior to the referendum and three months after.

Figure 2a: Conditional Volatilities of Stock Returns Scottish index excluding RBS and FTSE all share index June to December 2014

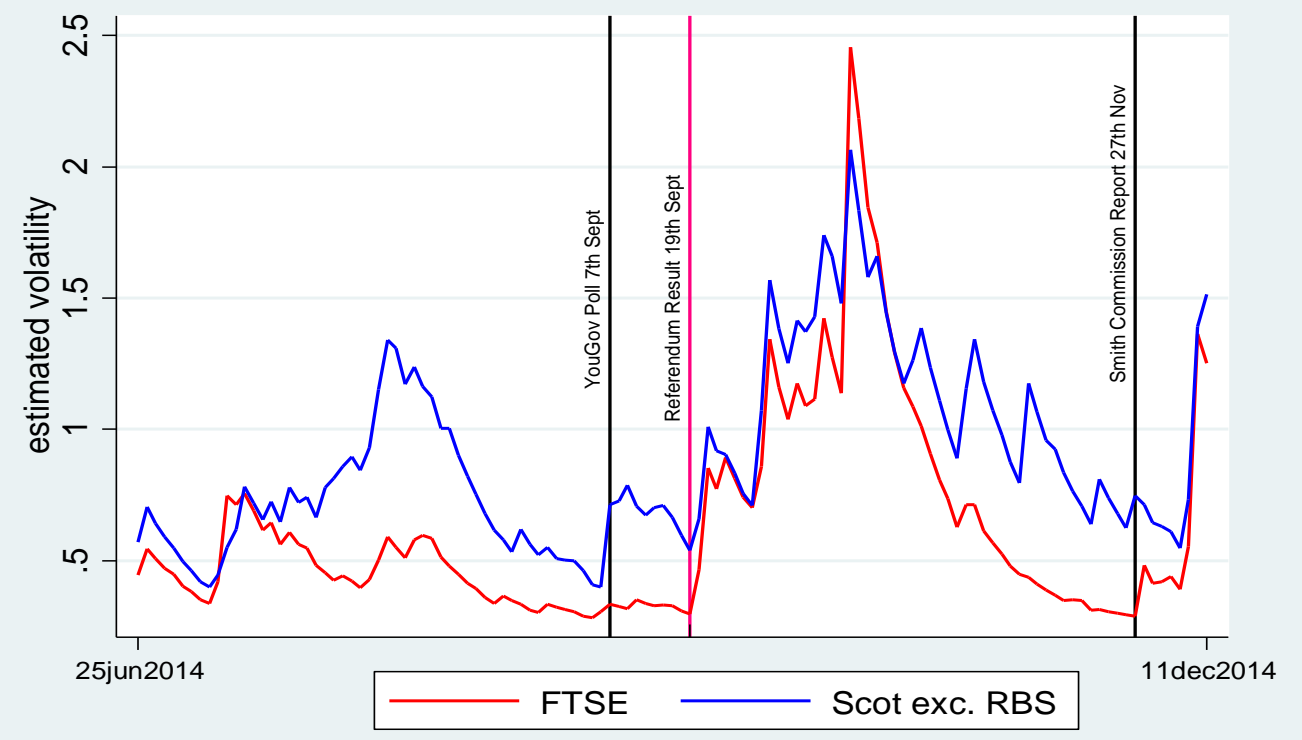

\footnotetext{
${ }^{8}$ The results are somewhat sensitive to the inclusion/exclusion of RBS. As mentioned previously, there are special factors to take into consideration. Nonetheless, for the interested reader, results that include the RBS are presented and discussed in Darby and Roy (2017).

9 This was the first election in 36 years to return a hung parliament, see Cawood (2013).
} 
Figure 2b: Relative Conditional Volatilities of Stock Returns

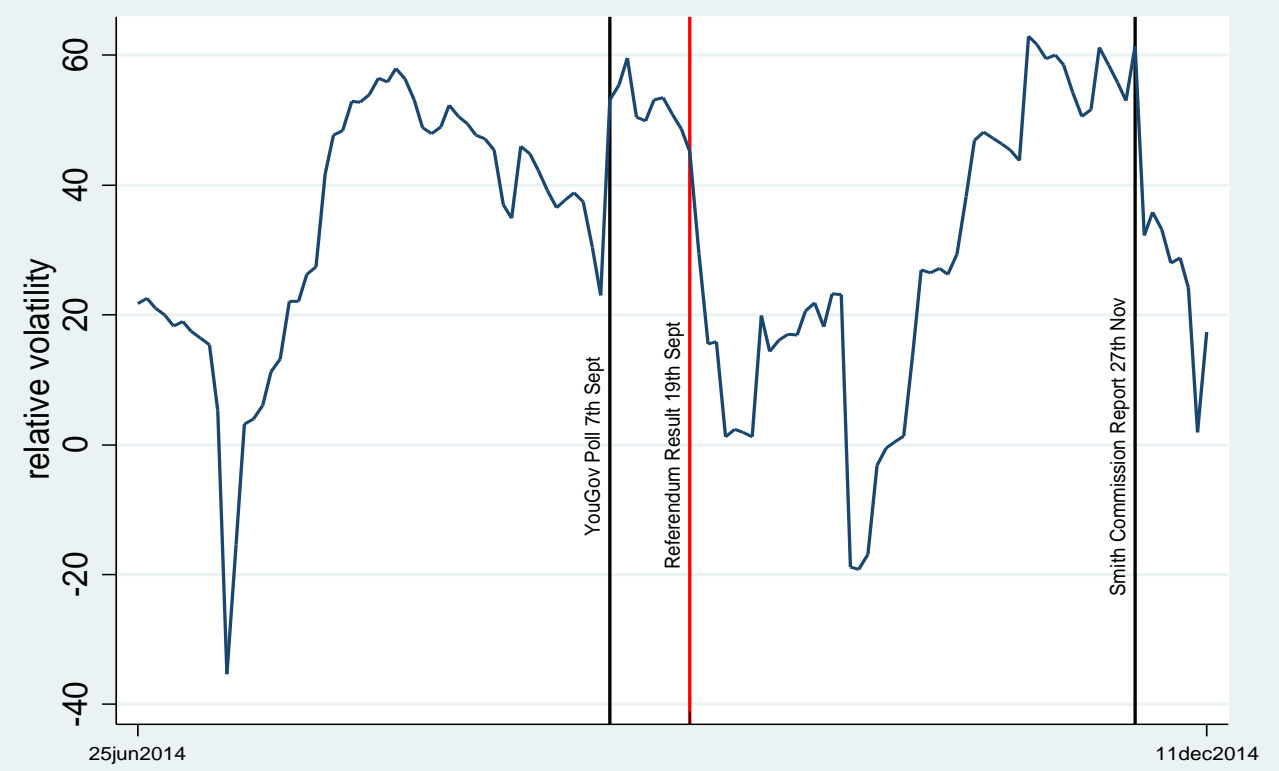

Figure $2 \mathrm{~b}$ plots a relative measure of estimated volatility, calculated as the percentage deviation in the Scottish series from the FTSE series: a positive number here means that the estimated level of volatility is higher in the Scottish series whilst a negative number indicates that volatility in higher for the FTSE series. Note the very clear jump up in the Scottish series when trading reacted to the YouGov poll published in the Sunday Times on $7^{\text {th }}$ September which put the Yes campaign in the lead. Heightened volatility continued until polling day, but receded immediately after the result. However, the referendum result did not signal the end of the story: there is further evidence of heightened relative volatility while the Smith Commission process was ongoing, this reached a local peak on the date of publication of the Commission's report $^{10}$.

\footnotetext{
10 There is also a spike in FTSE volatility, and decline in the relative volatility of the Scottish series on $15^{\text {th }}$ October 2014 - this reflected the large one day sell-off in major stock markets. At the time this was
} 


\section{Robustness Checks}

We repeat the analysis above for a Scottish series that excludes the whole of the finance sector and for another that make the additional exclusion of companies operating in the oil and gas sector. The broad findings described above remain, as indicated in Figure 4.

Figure 4: Relative Conditional Volatilities of Stock Returns Scottish indices and FTSE all share index, June to December 2014

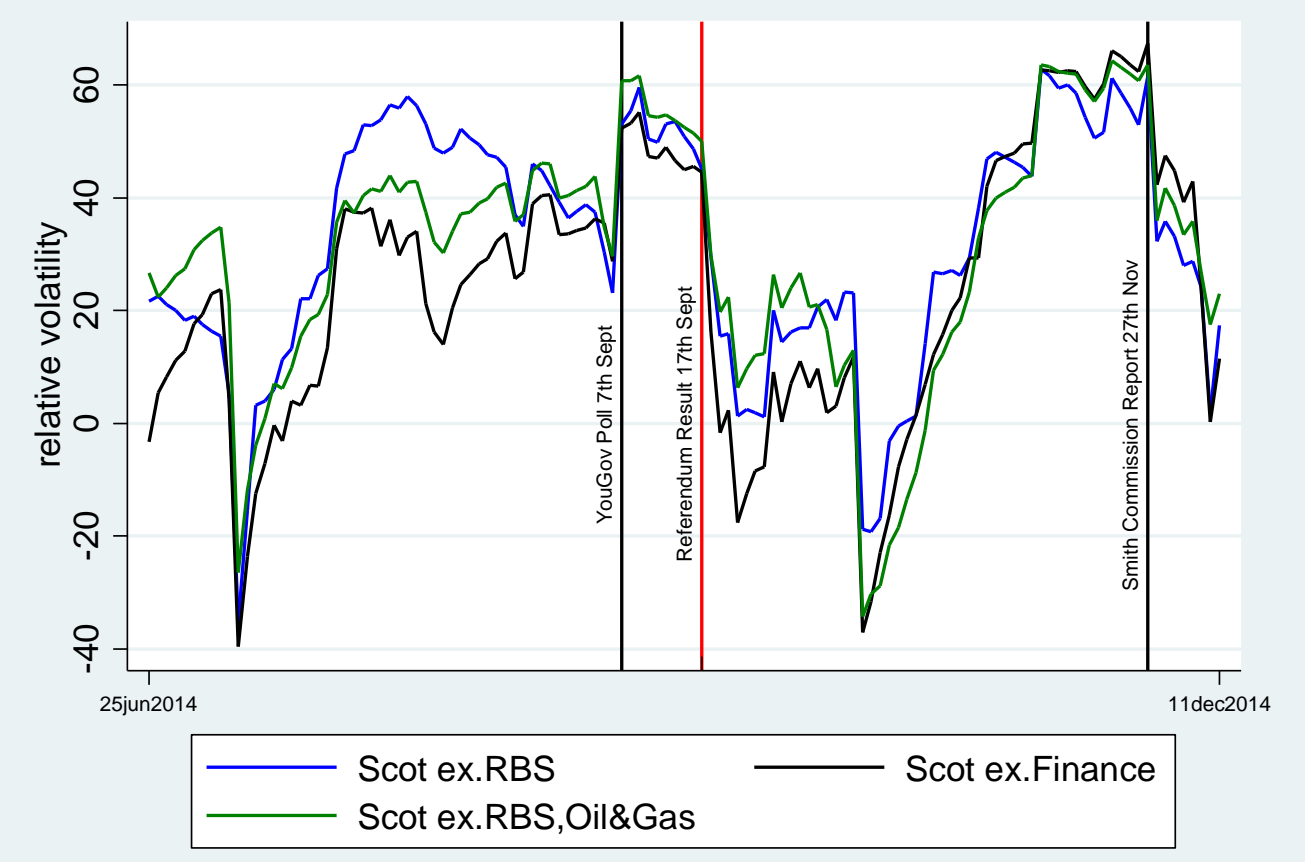

\section{Conclusions}

This paper has made a number of contributions to the existing literature. First, it identified Scottish companies listed on the London Stock Exchange during the 2014 Scottish Independence Referendum and constructed a capitalisation weighted Scottish stock price index. Second, it has investigated the volatility of stock returns of Scottish

widely attributed to worries about global growth and future interest rate policy of the US Federal Reserve. 
listed companies listed as compared to a FTSE all share benchmark. Third, through exploring how the volatility of stock returns evolves in the run up to and after the referendum, this paper contributes to the literature on the impact of political uncertainty outside 'normal' election cycles.

Key findings are i) that we cannot reject the null hypothesis that the conditional volatility of FTSE and Scottish (ex. RBS) stock returns can be characterised by the same GARCH parameters up to a sample period ending in late 2013; ii) that as the referendum date approaches this result is overturned, with the strength of the rejection increasing for the last 5 months prior to the referendum. A closer look reveals that the relative volatility of Scottish stock returns increased, reaching a peak after polls suggested the referendum race was too close to call. The volatility of Scottish stock returns then fell immediately after the result but climbed again prior to the publication of the Smith Commission report which set out proposed “extensive new powers” for the Scottish Parliament. These reactions of financial demonstrate that the referendum did not entirely resolve the uncertainty that both companies and investors faced.

It may be worthwhile to consider other extensions of this approach. There are some difficulties in making these kinds of comparisons to look at the implications of Brexit related uncertainty for stock market volatility since that situation is clearly still ongoing, with no EU countries ultimately likely to be completely unaffected. Another ongoing situation that could lend itself to this analytical approach currently faces companies based in Catalonia as compared to those based elsewhere in Spain. Finally, there is potentially scope to look at how individual companies' characteristics impact on estimated volatility of aggregate stock returns reported here. We leave these as suggestions of possible avenues for future research. 


\section{References}

Arin, K.P., Molchanov, A. and Reich, O.F.M. (2013) Politics, stock markets, and model uncertainty. Empirical Economics 45(1): 23.

Baker, S.R., Bloom, N. and Davis, S.J. (2013), Measuring Economic Policy Uncertainty, NBER Working Paper No. 21633.

Beaulieu, M.-C., Cosset, J.-C. and Essaddam, N. (2006), Political uncertainty and stock market returns: evidence from the 1995 Quebec referendum. Canadian Journal of Economics, 39: 621-642.

Białkowski, J., Gottschalk, K. and Wisniewski, T.P. (2008), Stock market volatility around national elections” Journal of Banking and Finance 32, 1941-1953.

Bollerslev, T., Engle, R.F. and Wooldridge, J.M. (1988). A Capital Asset Pricing Model with Time-Varying Covariances. Journal of Political Economy, 1988, vol. 96, issue 1, 116-31.

Business Insider Magazine, various issues. Scotland's Quoted Companies (regular feature). Available at www.insider.co.uk.

Cawood, I. (2013) Liberal-Conservative Coalitions - 'a farce and a fraud'? History and Policy, 10 May. Available at http://www.historyandpolicy.org/policypapers/papers/liberal-conservative-coalitions-a-farce-and-a-fraud.

Curtice, J. (2014). TNS Now Say It Is A Dead Heat. What Scotland Thinks, ScotCen Social Research. Available at http://blog.whatscotlandthinks.org/2014/09/tns-now-sayit-is-a-dead-heat/

Darby, J. and Roy, G. (2017) Political uncertainty and stock market volatility: new evidence from the 2014 Scottish Independence Referendum, Strathclyde University Discussion Paper in Economics No. 17-06.

Donders, M.W.M. and Vorst, T.C.F. (1996). The impact of firm specific news on implied volatilities. Journal of Banking and Finance, 20: 1447-146.

Ederington, L.H. and Lee, J.H. (1993). How markets process information: News releases and volatility. Journal of Finance, 48: 1161-1191.

Ederington, L.H. and Lee, J.H. (1996) The creation and resolution of market uncertainty: the impact of information releases on implied volatility. Journal of Financial and Quantiative Analysis, 31: 513-539.

Financial Times (2014), “Standard Life warns on Scots 'Yes' vote”, article available at www.ft.com/content/5c266dd0-9f83-11e3-94f3-00144feab7de?mhq5j=e3

Glosten, L.R., Jagannathan, R. and Runkle, D.E. (1993). On the relation between the expected value and the volatility of the nominal excess return on stocks. Journal of Finance, 48(5) 1779-1801. 
Goodell, J.W. \& Vähämaa, S. (2013). U.S. presidential elections and implied volatility: The role of political uncertainty. Journal of Banking and Finance, Vol. 37, No. 3, pp. $1108-1117$

London Stock Exchange (various years) Historic company files, available at www.londonstockexchange.com/statistics/historic/company-files/company-files.htm

Marsh, P and Evans, S. (2014) The SCOTSIE 100: sixty years of Scottish Stocks, Walbrook Economics. Available at http://www.walbrookeconomics.co.uk/articles/scotsie-100-sixty-years-scottish-stocks

National Centre for Social Research (2014) "What Scotland Thinks" http://whatscotlandthinks.org/questions/should-scotland-be-an-independent-country\#line

Nelson, B. D. (1991) Conditional heteroskedasticity in asset returns: a new approach, Econometrica, 59, 347-70.

Pástor, L. and Veronesi, P. (2013). Political uncertainty and risk premia. Journal of Financial Economics 110, 520-545.

Pástor, L., and Veronesi, P. (2012). Uncertainty about government policy and stock prices. Journal of Finance 67, 1219-1264.

Scottish Government (2013) Scotland's Future: Your Guide to an Independent Scotland. 29th November, http://www.gov.scot/Resource/0043/00439021.pdf.

Scottish Government (2014) Scottish Independence Bill: A consultation on an interim constitution for Scotland. 16 ${ }^{\text {th }}$ June, http://www.gov.scot/Publications/2014/06/8135.

The Smith Commission (2014). Report on further devolution of powers to the Scottish Parliament. $27^{\text {th }}$ November, Avaialble at:

http://webarchive.nationalarchives.gov.uk/20151202171017/http://www.smithcommission.scot/wp-content/uploads/2014/11/The_Smith_Commission_Report-1.pdf.

Smales, L. (2014) Political uncertainty and financial market uncertainty in an Australian context. Journal of International Financial Markets, Institutions and Money

UK Government (2014), “United Kingdom, united future: Conclusions of the Scotland analysis programme”, 19 June 2014, HM Treasury and Scotland Office. Available at www.gov.uk/government/publications/united-kingdom-united-future-conclusions-ofthe-scotland-analysis-programme

Vähämaa, S. and Äijö, J. (2011). The Fed's policy decisions and implied volatility. Journal of Futures Markets, 31: 995-1009.

Vuchelen, J. (2003), Electoral systems and the effects of political events on the stock market: The Belgian case. Economics and Politics, 15: 85-102. 